\title{
Characteristics of poisoning cases in Adiyaman city
}

\author{
Adıyaman ilinde zehirlenme hastalarının özellikleri
}

\section{Öznur Uludağ ${ }^{1}$, Atilla Tutak${ }^{1}$, Mevlüt Doğukan¹, Recai Kaya ${ }^{1}$, Ayşe Şahin Tutak², Mustafa Çelik ${ }^{3}$}

\begin{abstract}
Objective: Aim of this study was to retrospectively evaluate poisoning cases in an intensive care unit (ICU) in order to determine the profile of poisoning cases, update epidemiological data in Adiyaman, and contribute to data about poisoning in our country.
\end{abstract}

Methods: Between 01-01-2012 and 31-12-2013 174 patients (116 males, 58 females) with a mean age of 23.7 years were treated. Demographic characteristics, reasons and ways of poisoning, types of toxic substances, length of their ICU stay and prognosis were evaluated.

Results: 2733 patients admitted to the intensive care unit were 174 poisoning cases. Poisoning ways were suicide by drug overdose $(n=162,93.1 \%)$, and accidental poisoning $(n=12,6.9 \%) .119$ patients $(66.5 \%)$ had single drug intake, thirty-three patients $(18.4 \%)$ with multiple drug intake, and $16(8.9 \%)$ were poisoned by organic phosphates. The most common drug used for suicide was antidepressants $(n=87.5 \%) .32$ patients (18.4\%) took analgesics and anti-inflammatory drugs. A total of 152 patients taking the drug, 22 patients were poisoned by other means. The median length of patient stay was 2 days (range 1-20 days).

Ninety-nine patients $(56.9 \%)$ recovered and were discharged.72 patients (41.4\%) were admitted to inpatient after intensive care unit. Patients were followed up by asking poisoning suicidal psychiatric consultation.1 patient was followed up for 20 days in intensive care due to alcohol poisoning but was died.2 patients $(1.1 \%)$ were referred to a center forward.

Conclusion: Majority of the patients were females, who took drugs with suicidal intention. Frequent use of antidepressants, which are not subject to control by authorities, to commit suicide was remarkable.

Key words: Intensive care unit, poisoning, suicide, antidepressant drugs

\section{ÖZET}

Amaç: Çalışmamızda yoğun bakım ünitesinde tedavi edilen zehirlenme olguları retrospektif incelenerek ilimize ait zehirlenme vakalarının profilini belirlemek, epidemiyolojik çalışmaların güncellenmesine ve ülkemizin zehirlenme verilerine katkıda bulunmak amaçlandı.

Yöntemler: Yoğun bakım ünitesinde 01.01.201231.12.2013 tarihleri arasında zehirlenme nedeni ile 174

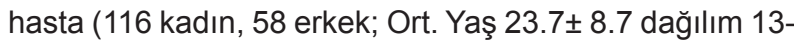
53) takip ve tedavi edildi. Hastalar demografik özellikleri, zehirlenme neden ve yolları, alınan toksik maddenin türü, yatış süreleri ve prognozlarına göre değerlendirildi.

Bulgular: Yoğun bakım ünitesine kabul edilen 2733 hastanın 174'ü zehirlenme olgusu idi. Zehirlenme yolu; intihar amaçlı ilaç alımı ( $n=162, \% 93,1)$ ve kaza ile zehirlenme $(n=12, \% 6,9)$ idi. Yüzondokuz hasta $(\% 68,4)$ tekli ilaç alımı, 33 hasta $(\% 18,4)$ çoklu ilaç alımı, 16 hasta $(\% 9,2)$ organik fosfat nedeni ile zehirlenmişti. İntihar amacıyla alınan ilaçlar arasında en sık etken antidepresan $(n=87, \% 50)$ ilaçlardı. Bunu otuz iki hasta $(\% 18,4)$ ile analjezik ve antienflamatuar ilaçlar takip etti. Toplam 152 hasta ilaç alarak 22 hasta diğer yollarla zehirlenmişti. Hastaların ortanca yatış süresi 2 gün (dağılım 1-20 gün) idi. Hastaların 99'u $(\% 56,9)$ iyileşerek taburcu edildi.72 hasta $(\% 41,4)$ yoğun bakım sonrası yataklı servise yatırıldı. 1 hasta $(\% 0,6)$ alkol zehirlenmesi nedeniyle 20 gün yoğun bakımda takip edildi. Ancak yaşamını yitirdi. 2 hasta $(\% 1,1)$ ileri bir merkeze sevk edildi.

Sonuç: Hastaların büyük çoğunluğunun intihar amacıyla ilaç alan genç kadın hastalar olduğu görüldü. İntihar için sıklıkla reçete kontrolüne tabi olmayan antidepresanların kullanılması dikkate değerdir.

Anahtar kelimeler: Yoğun bakım ünitesi, zehirlenme, intihar, antidepresan ilaçlar

\footnotetext{
${ }^{1}$ Department of Anesthesiology and Reanimation, Faculty of Medicine, Adiyaman University Medical School, Adiyaman, Turkey ${ }^{2}$ Department of Internal Medicine, Faculty of Medicine, Adiyaman University Medical School, Adiyaman, Turkey ${ }^{3}$ Department of Psychiatry, Faculty of Medicine, Adiyaman University Medical School, Adiyaman, Turkey
}

Yazışma Adresi /Correspondence: Öznur Uludağ,

Department of Anesthesiology and Reanimation, Faculty of Medicine, Adıyaman University Medical School, Adıyaman, Turkey Email: uludagoznur@gmail.com 


\section{INTRODUCTION}

Substances that cause chemical and physiological effects in human body which can lead to death when taken at toxic doses are called poisons and cluster of clinical symptoms due to damage produced in tissues by these substances is called poisoning. Toxic response after exposure depends on physical properties of the toxic substance, way of entry into the body, and personal susceptibility to the specific substance. Poisonings may be due to suicidal intake of substances or drugs, accidental use of high doses of drugs, and adverse drug reactions [1].

Poisoning is an important health problem in whole world and it is an important cause of patient admissions to intensive care units (ICU) especially in developing countries. Although the incidence of poisonings vary among countries which is reported to be between 0.07 and $0.7 \%$ in developing countries [2].

Epidemiological data indicates that poisonings are most common seen in females between 15 and 35 years due to suicidal intake of drugs, particularly antidepressants [3].

Importance of epidemiological data to develop national and especially local health policies is growing day by day and frequent revisions are needed. Thus, we retrospectively evaluated two years data of our ICU in order to determine the frequency and profile of poisoning cases treated in our ICU.

\section{METHODS}

The study began after approval of Ethics Committee of Adiyaman University Medical School (No: 57831858/71). This study included 174 poisoning cases treated in general ICU of Adiyaman University Research and Education Hospital between 01-January-2012 and 31-December-2013. Age, sex, reason of poisoning (suicidal, accidental), type of poisoning (single drug use, multiple drug use, chemical substance, organic phosphate, mushroom, inhalants, alcohol, pesticide, taken substance (antidepressant, analgesic-antiinflammatory drugs, mushroom, antithyroid, antiepileptic, antibiotic, organic phosphate, antihypertensive, proton pump inhibitor, antidiabetic, alcohol, household bleach), ICU stay period (days), and prognosis (discharge, transfer to another ward, referral to a higher center) were recorded.
Statistical evaluation of data was performed using SPSS 21.0 package program. Mean, standard deviation and percentage values were used as descriptive statistics. Chi square and independent sample $t$ tests were used for data analyses. $\mathrm{P}<0.05$ was accepted as statistically significant.

\section{RESULTS}

Between 01.01.2012 and 31.12.2013 2733 patients were admitted to ICU. Among these admissions 174 were due to poisonings. The study group included $116(66.7 \%)$ females and $58(33.3 \%)$ males. Mean age of the patients was $23.7 \pm 8.7$ years (range 1353 ). Mean age of the females was $22.2 \pm 7.7$ years, and males was $26.6 \pm 9.7$ years. Males were older than females $(p=0,012)$. Demographic data of the patients is given in Table 1.

Table 1. Demographic data

\begin{tabular}{lccc}
\hline & $\begin{array}{c}\text { Female } \\
\mathbf{n ~ ( \% )}\end{array}$ & $\begin{array}{c}\text { Male } \\
\mathbf{n}(\%)\end{array}$ & $\begin{array}{c}\text { Total } \\
\mathbf{n}(\%)\end{array}$ \\
\hline Age (year) & $22.2 \pm 7.2$ & $26.9 \pm 9.7$ & \\
Reason of poisoning & $116(66.7)$ & $58(33.3)$ & $174(100)$ \\
$\quad$ Suicide & $110(63.3)$ & $52(29.9)$ & $162(93.2)$ \\
Accidental & $6(3.4)$ & $6(3.4)$ & $12(6.8)$ \\
Total & $116(66.7)$ & $58(33.3)$ & $174(100)$ \\
Type of poisoning & & & \\
Using drug & $102(58.6)$ & $50(28.7)$ & $152(87.3)$ \\
Other & $14(8.1)$ & $8(4.6)$ & $22(12.7)$ \\
\hline Total & $116(66.7)$ & $58(33.3)$ & $174(100)$ \\
\hline
\end{tabular}

Types of poisoning are given in Table 2. Drugs were used by $152(87.3 \%)$ patients; 102 of these patients were females and 50 were males. No gender difference was found for type of poisoning.

Table 2. Type of poisoning

\begin{tabular}{lc}
\hline & $\mathbf{n}(\%)$ \\
\hline Single drug intake & $119(68.4)$ \\
Multiple drug intake & $33(18.9)$ \\
Organic phosphate & $16(9.2)$ \\
Household chemical & $2(1.1)$ \\
Mushroom & $1(0.6)$ \\
Inhalant (Solvent, Toluen) & $1(0.6)$ \\
Alcohol & $1(0.6)$ \\
Pesticide & $1(0.6)$ \\
\hline
\end{tabular}


Mean age of the 152 patients who used drugs was 22.6 \pm 7.1 and mean age of patients who used methods other than drugs was $31.1 \pm 13.8$. Patients who used drugs for poisoning were younger than patients who used the other methods $(\mathrm{p}<0.05)$.

Reason of poisoning was suicide in 162 patients (93.2\%) and accident in $12(6.8 \%)$ patients. No gender difference was found for reason of poisoning.

Substances taken by the patients are given in Table 3 . In $50 \%$ of poisonings $(n=87)$ antidepressant drugs were used. This was followed by antiinflammatory-analgesic drugs $(\mathrm{n}=32 ; 18.4 \%)$.

Table 3. Substance taken by the patients

\begin{tabular}{lc}
\hline & $\mathbf{n}(\%)$ \\
\hline Antidepressant & $87(50.0)$ \\
Analgesic / anti-inflammatory & $32(18.4)$ \\
Unknown & $17(9.8)$ \\
Organic phosphate & $16(9.2)$ \\
Antihypertensive & $12(6.9)$ \\
Antibiotic & $9(5.2)$ \\
Antiepileptic & $5(2.9)$ \\
Proton pump inhibitor & $3(1.7)$ \\
Antidiabetic & $2(1.0)$ \\
Household chemical (bleach) & $2(1.0)$ \\
Alcohol & $2(1.0)$ \\
Iron including drugs & $2(1.0)$ \\
Pesticide & $1(1.0)$ \\
Inhalant (solvent, toluene) & $1(1.0)$ \\
\hline
\end{tabular}

Mean ICU stay times according to reason of poisoning and type of poisoning are given in Table 4. Mean ICU stay of all patients was $2 \pm 2$ days. Male patients $(2.5 \pm 3)$ were detected to stay longer in ICU than females $(1.8 \pm 1)$. No significant difference was found between ICU stay times of accidental and suicidal poisonings.

Table 4. Intensive care unit (ICU) stay times of the patients

\begin{tabular}{llcc}
\hline ICU Stay Time & & Mean \pm SD (day) & $\mathbf{n}$ \\
\hline Sex & Female & $1.8 \pm 1.0$ & 116 \\
\multirow{4}{*}{ Reason of Poisoning } & Male & $2.5 \pm 3.0$ & 52 \\
\cline { 2 - 3 } Type of Poisoning & Accidental & $2.0 \pm 2.0$ & 162 \\
& Drug & $1.0 \pm 1.5$ & 12 \\
& Other & $3.5 \pm 4.0$ & 152 \\
& & \\
\hline
\end{tabular}

Poisonings with single or multiple drug intake stayed shorter in ICU than poisonings with other substances.

Ninety-nine patients $(56.9 \%)$ were discharged after recovery. Seventy two $(41.4 \%)$ patients were transferred to inpatient wards after ICU treatment. A patient stayed for 20 days in ICU due to alcohol intoxication but died. Two patients $(1.1 \%)$ were followed in ICU for a day due to organic phosphate poisoning and undetected single drug poisoning and then were referred to a higher center. Seventy one female and 28 male patients were discharged after recovery. No difference in prognosis could be detected between patients who took drugs or other substances for poisoning. Prognoses of suicidal and accidental poisonings were also similar. Prognosis of poisoning patients admitted to our ICU is shown in Table 5.

Table 5. Prognosis according to gender

\begin{tabular}{lccc}
\hline & Discharge & Other & Total \\
\hline Female & 71 & 45 & 116 \\
Male & 28 & 30 & 58 \\
\hline Total & 99 & 75 & 174 \\
\hline
\end{tabular}

Table 6. Outcome

\begin{tabular}{lc}
\hline Outcome & $\mathbf{n ~ ( \% )}$ \\
\hline Discharge & $99(56.9)$ \\
Transfer to a ward & $72(41.4)$ \\
Exitus & $1(0.6)$ \\
Referral to a higher center & $2(1.1)$ \\
Total & $174(100)$ \\
\hline
\end{tabular}

\section{DISCUSSION}

Between 01.01.2012-31.12.2013 2733 patients were treated in Adiyaman Research and Education Hospital ICU and $174(\% 6.36)$ of these patients were due to poisoning. This low rate may be due to this ICU being the only one in the city and accepting patients from both surgical and clinical branches.

Our patient group involved 116 females $(66.7 \%)$ and 58 males $(33.3 \%)$. A study investigating 986 poisoning cases presented to emergency department found that $675(68.5 \%)$ were females and $311(31.5 \%)$ were males [4]. A retrospective study 
about poisoning cases in an ICU found 109 (69.4\%) and $48(30.5 \%)$ male cases [5]. Another ICU study investigating poisoning cases for 4 years found that $61 \%$ of the cases were females and $39 \%$ were males [6]. In previous studies intoxications were more common in females and female/male ratio was reported to be 2 or $3[7,8]$. Our study also showed female dominance at a rate of $2 / 1$.

Ages of the cases were between 13 and 53 . Mean age of females was $22 \pm 7$, and males was $26 \pm 9$. Previous studies reported that suicide attempts were common in females younger than 25 years and in males between 25 and 30 years of age $[9,10,11]$. Our study also showed that male poisoning cases were older than females.

Using a medicine was the way of poisoning in $152(87.3 \%)$ patients. Among them 119 (68.4\%) patients were intoxicated by a single drug and 33 (18.9\%) patients with multiple drugs. Drug intoxication is a common way of poisoning also in literature and involves $60-70 \%$ of the cases admitted to hospitals [7,12].

Causes of intoxication other than drugs varies between countries. In Western countries alcohol and narcotic substance intoxications are predominant [13] while in our country carbon monoxide (CO) poisonings and food intoxications follow poisonings due to drugs. A study from Cerrahpaşa Medical School reported that $69.39 \%$ of the poisoning cases were due to drug intoxications, $14.44 \%$ were due to CO, $5.99 \%$ were due to alcohol, $3.17 \%$ were due to food, $1.76 \%$ were due to corrosive substances and $1.06 \%$ were due to pesticides [7].

We detected that drugs were responsible from poisonings in $87.4 \%$, organic phosphate in 9.25 , corrosive substances in $1.1 \%$, and mushroom, solvent, alcohol and pesticides each in $0.6 \%$ of cases.

In previous studies poisonings due to $\mathrm{CO}$ were found in 9\% [14], 7.64\% [5], and 6.9\% [15] of cases. We didn't come across with a case of carbon monoxide poisoning in 2 years period. Common use of natural gas for heating in our region, mild climate conditions, and efforts by public health authorities regarding use of stoves may be the reasons for this.

Organophosphates are commonly used in our country in agriculture. Poisoning cases may be due to ignorant or uncontrolled use or suicidal use of or- ganophosphates. A 2007 report of American Association of Poison Control found that $3.9 \%$ of poisoning cases were due to organophosphate intoxication. Data from Poison Information Center of Dokuz Eylül Medical School found that agricultural drug poisonings were second in prevalence and found in $8 \%$ of cases presented to this center between January 1993 and December 2001.

We found organophosphate poisoning in $9.2 \%$ of cases. Eleven $(68.7 \%)$ of these cases were females and $5(31.2 \%)$ of them were males. Ten $(62.5 \%)$ of these cases were oral intakes for suicide, and $6(37.5 \%)$ cases were accidental intakes. Their stay time in ICU was 2.5 days. Ten $(62.5 \%)$ of these cases were discharged with recovery. Five (31.2\%) of these cases were transferred to another ward. A 27 years old, accidentally poisoned female was referred to a higher center after one day of treatment in ICU. Two males and 4 females were exposed to organic phosphates accidentally. We think higher exposure of females to organic phosphates is due to higher employment of females in agriculture.

In studies with large sample sizes $95 \%$ of poisoning cases followed in ICU's were found to be due to suicidal attempts and they were mostly young females [16]. Özcan et al reported that $86.6 \%$ of poisonings were due to suicidal attempts and $13.4 \%$ were accidental [5]. Kaya et al found that $98 \%$ of poisonings were due to suicidal attempts [17]. Özayar et al found that $87 \%$ of poisonings were due to suicidal attempts [18]. In our study suicidal poisonings were responsible from $93.1 \%$ and accidental poisonings were responsible from $6.9 \%$ of the cases.

Gündüz et al [19] reported that $77 \%$ and Yağan et al [20] reported that $70 \%$ of poisonings due to suicidal attempts were females. In our study $63.2 \%$ of poisonings due to suicidal attempts were females. We think that high rate of females in suicidal attempts in Adiyaman city may be due to social pressure on women, inadequate social services for women, and other socio cultural problems which lead to perception of hopelessness of women.

Mean ICU stay time for poisoning cases was $2.02 \pm 1.91$ days. Mean stay time for intoxications with single or multiple drugs was shorter than poisoning with other substances. 
Ninety nine $(56.9 \%)$ patients were discharged from ICU with recovery. Seventy two patients $(41.4 \%)$ were transferred to an inpatient ward. One patient died after 20 days of treatment in ICU.

\section{CONCLUSION}

Antidepressant and analgesic / anti-inflammatory drug intoxication for suicide attempt by young women was the most common type of poisoning in cases treated in our ICU. This may be due to social pressure on young women leading to high rates of suicidal attempts, and widespread availability of these drugs due to lack of prescription controls for them. By detection of poisoning data in our city precautions can be implemented and future targets can be determined.

\section{Conflict of Interest}

The authors don't report any conflict of interest.

\section{REFERENCES}

1. Dökmeci İ. Toksikoloji, Akut zehirlenmelerde tanı ve tedavi. 2. Bask1 İstanbul, Nobel Tıp Kitabevi 1994;1-10.

2. Șencan A, Adanır T, Aksun M, et al. Yoğun bakıma kabul edilen akut zehirlenme olgularında bireysel ve etiyolojik özelliklerin mortalite ile ilişkisi. Türk Anesth Rean Dergisi 2009;37:80-85.

3. Mauri MC, Cerveri G, Volonteri LS, et.al. Parasuicide and drug self-poisoning: analysis at the epidemiological and clinical variable of the patients admitted to the Poisoning Treatment Centre (CAV), Niguarda General Hospital, Milan. Clin Pract Epidemol Ment Health 2005;1:1-8.

4. Al B, Güllü MN, Küçüköner M, et al. Dicle Üniversitesi Tıp Fakültesi Acil Servisine ilaçlara bağlı zehirlenmeler nedeni ile başvuran hastaların epidemiyolojik özellikleri. Toksikoloji Dergisi 2006;4:11-20.

5. Özcan N, Özcan A, Kantekin Üç, et al. Hastanemiz reanimasyon ünitesinde tedavi edilen akut intoksikasyon olgularinin retrospektif olarak değerlendirilmesi. Anestezi Dergisi 2010;18:159-162.

6. Sverrisson KO, Palsson SP, Sigvaldoson K, et al. Clinical aspects and follow up suicide attepts treated in a general intensive care unit at Ladspitali University Hospital in İCELAND 2000-2004. Laeknabladid 2010;2:101-107.

7. Tufekci İB, Cungurlu A, Şirin F. Characteristics of acute adult poisoning cases admitted to a university hospital in İstanbul. Hum Exp.Toxicol 2004;23:347-351.

8. Özköse Z. Ayoğlu F. Etiological and demographical characteristics of acute adult poisoning in Ankara, Turkey. Hum Exp Toxicol 1999;18:614-618.

9. Haderson A, Wright M, Pond SM. Experience with 732 acute overdose patients admitted to an intensive care unit over six years. Med J Aut 1993;158:28-30.

10. Kaygusuz K, Gürsoy S, Kilıçcıoğlu F, et al. Cumhuriyet Üniversitesi Tıp Fakültesi Hastanesi Yoğun bakım ünitesinde 1998-2004 y1lları arasında akut ilaç zehirlenmesi tanısı ile takip edilen olguların geriye dönük analizi. CÜ Tip Fakültesi Dergisi 2004;26:161-165.

11. Yıldız H, Doğan Z, Şenoğlu N, et al. Yoğun Bakım Ünitemizde 2004-2009 yılları arasında takip edilen zehirlenme olgularının geriye dönük değerlendirilmesi. Journal of The Turkish Society of İntensive Care 2009;7:161-165.

12. Seydaoğlu G, Satar S, Alparslan N. Frequency and mortality risk factors of acute adult poisoning in Adana, Turkey, 1997-2002. Mt Sinai J Med 2005;72:393-401.

13. Dorado Pombo S, Martin Fernandez J, Sabugal Rodelgo G. Epidemiology of acute poisoning: study of 613 cases in the community of Madrid in 1994. Rev Clin Esp 1996;196:150156.

14. Yılmaz A, Güven FK, Korkmaz İ, Karabulut S. Acil Serviste akut zehirlenmelerin retrospektif analizi. CÜ. Tıp Dergisi 2006;28:21-26.

15. Akköse Ş, Fedakar R, Bulut M, Çebiçci H. Zehirlenme olgularının beş yıllık analizi. Turk J Emerg Med 2003;3:810.

16. Fuller GN, Rea AJ, Payne JF, Lant AF. Parasuicide in central London 1984-1988. JR Soc Med 1989;82:653-656.

17. Kaya S, Kararmaz A, Karaman H, Turhanoğlu S. Yoğun Bakımdaki Zehirlenme Olgularının Geriye Dönük Analizi. Dicle Tip Dergisi, 2006;33:242-244.

18. Özayar E, Değerli S, Güleç H, et al. Yoğun Bakımda İntoksikasyon Olguları. Yoğun Bakım Dergisi 2011;3:59-62.

19. Gündüz A, Kesen J, Topbaş M, et al. Analysis of suicidal poisoning patients presented to emergency department TSK Koruyucu Hekimlik Bülteni 2004;3:234-242.

20. Yağan Ö, Akan B, Erdem D, et al. The retrospective analysis of the acute poisoning cases applying to the emergency unit in one year. Şişli Etfal Hastanesi Tıp Bülteni 2009;43:6064. 